ISSN:2528-9527

E-ISSN : 2528-9535

YIl Year: 8

Cilt Volume: 8

Sayı Issue :Gençlik Araştırmaları Özel Sayısı

Mart March 2018

\title{
Azərbaycanda Gənclər Siyasəti və Onun Turizmin İnkişafına Təsiri
}

DOI: $10.26466 /$ opus.385428

$*$

\section{$\underline{\text { Rəna Sultanova* }}$}

*Prof., Dr., AMEA-nın İqtisadiyyat İnstitutu,ş̈bə müdiri, i.e.d, İnstitute of Economy of Azerbaijan National Academy of Sciences, Director of department. Nahcivan

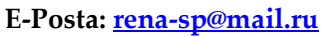
ORCID: 0000-0001-5488-1024

\section{Öz}

Maqalada ölkada aparılan ganclar siyasati tahlil olunaraq, onun turizmin inkişafina tasiri göstarilmişdir. Burada müallif bölgalarda turizmin inkişafının tamin olunmasında ganclarin faaliyyatini qiymatlandirarək, onlara müvafiq şəraiti yaradılmasl, yüksək ixtisaslı kadrların bu sahəya calb olunması va ehtiyaclarmm ödanilmasi kimi masalalara diqqat yetirir. Sonda ganclarin hartarafli inkişafı va sosial müdafiasinin güclandirilmasina dair təkliflar irali sürülmüşdür.

Açar sözlər: gənclar siyasəti, turizm, bölgə, sosial müdafiə, ixtisaslı kadr,məşğulluq

OPUS ( $)$ Uluslararası Toplum Araştırmaları Dergisi-International Journal of Society Researches ISSN:2528-9527 E-ISSN : 2528-9535

http://opusjournal.net 


\title{
Youth policy in Azerbaijan and its influence on tour- ism development
}

\begin{abstract}
The article analyzes the youth policy carrying out in the country and its impact on the development of tourism. The author gives attention to the issues of creating favorable conditions for them, involving highly qualified personnel in this field and meeting their needs assessing the activity of youth in the development of tourism in the regions. In the end proposals were made to develop comprehensively and strengthen the social protection of youth.
\end{abstract}

Keywords: youth policy, tourism, region, social protection, qualified personnel, employment

OPUS @ C Uluslararası Toplum Araştırmaları Dergisi-International Journal of Society Researches ISSN:2528-9527 E-ISSN : 2528-9535

http://opusjournal.net 


\section{Giriş}

Ölkənin dinamik inkişafı həmişə gənclərlə bağlı olmuşdur ki, bu da ilk növbədə, onların ictimai həyatın bütün sahələrində fəal olmasıdır.

$\mathrm{Bu}$ günləri Azərbaycan gəncləri ölkə iqtisadiyyatının bütün sahələrində, o cümlədən turizm sahəsində və dövlət strukturlarında çalışaraq, öz gücünü əsirgəmirlər. , gənclər dövlətin qayğısını daim öz üzərində hiss edir.

Belə ki, 2002-ci ildə "Gənclər siyasəti haqqinda" Azərbaycan Respublikasının Qanunu qəbul edilmişdir/

Son illərdə gənclərlə bağlı bir sıra dövlət proqramları qəbul olunmuşdur ki, onlardan 2005-ci və 2011-ci illərdə "Azərbaycan gəncliyi Dövlət" müdiriyyət , 2007-2015-ci illərdə "Azərbaycan gənclərinin xarici ölkələrdə təhsili üzrə Dövlət vurmüdiriyyət ğulamaq olar. Bu müdiriyyət azərbaycan gənclərinə xarici ölkələrin ali təhsil məktəblərində təhsillərini başa çatdırılmasına və ölkənin inkişafına xidmət etmələrinə imkan yaradır (Milli Məclis, 2014, s. 85).

Ölkə əhalisinin 2,7 milyon nəfərini və ya 28,1 faizini gənclər təşkil edir və onların 52 faizi şəhər yerlərində, 48 faizi isə kənd yerlərində məskunlaşıb [Sultanova R.P., 2016, s. 464].

\section{Azarbaycanda turizmin inkişaf hadaflari}

Hazırda azərbaycan gənclərini daha çox cəlb edən sahə turizmdir ki, o, da dünya iqtisadiyyatının ən surətlə inkişaf edən sektorlardan biridir.

Turizm ölkə iqtisadiyyatının bir xidmət sahəsi kimi, dövlət büdcəsinin formalaşmasına, ticarət balansının sabitləşməsinə, işsizliyin aradan qaldırılmasına köməklik edən bir sahədir.

Onu da vurğulamaq lazımdır ki, turizm sahəsi dünyada sülhün möhkəmləndirilməsinə, ölkələrarası əlaqələrin genişlənməsinə, ayrı-ayrı xalqların mədəni irsinin öyrənilməsinə, müxtəlif millətlərin yaxınlaşmasına imkan yaradır. 
Belə ki, 2016-c1 ildə qəbul edildimiştir "Azərbaycan Respublikasında ixtisaslaşmış turizm sənayesinin inkişafına dair Strateji Yol Xəritəsi"ndə 2020-ci ilədək qəbul edilmiş hədəflərin reallaşması nəticəsində Azərbaycanda 2020-ci ildə real ÜDM - in birbaşa 293 milyon və dolay1 172 milyon manatadək artacağı, cəmi 35 min olmaqla bilavasitə turizm sahəsində $25 \mathrm{~min}$ iş yerinin yaradılacağı proqnozlaşdırılır. Dövlət - özəl resursları hesabına 350 milyon manat həcmində investisiya qoyuluşunu istəmişdir. Aşağıda olan cədvəl 1-də Strateji Yol Xəritəsi çərçivəsində görünəcək tədbirlər öz əksini tapmışdır.

Cadval 1: Strateji Yol Xəritəsi çərçivəsində görüləcək tədbirlər üzrə gözlənilən nəticələr

\begin{tabular}{|c|c|c|c|c|}
\hline № & Prioritetin adresi & $\begin{array}{l}\text { ÜDM-ə } \\
\text { təsiri } \\
\text { (milyon } \\
\text { 2020) }\end{array}$ & $\begin{array}{l}\text { Maşğgulluq } \\
\text { (tam ştatlı } \\
\text { işçilar, } \\
\text { 2020) }\end{array}$ & $\begin{array}{c}\text { İnvestisiya } \\
\text { məbləği } \\
(\text { milyon })\end{array}$ \\
\hline 1.1 & $\begin{array}{l}\text { Milli Turizm Təbliğat } \\
\text { Bürosu-nun yaradıl- } \\
\text { ması və ilk olaraq } \\
\text { Bakı şəhərində olması }\end{array}$ & 10 & - & - \\
\hline 1.2 & $\begin{array}{l}\text { Bakı şəhərindəki cəl- } \\
\text { bedici turizm məkan- } \\
\text { larına dair məlumat- } \\
\text { ların və turist xidmət } \\
\text { pa-ketlərinin yeni- } \\
\text { lənməsi }\end{array}$ & 50 & 8.500 & 15 \\
\hline 1.3 & $\begin{array}{l}\text { Bakı şəhəri üzrə təbli- } \\
\text { ğat-təşviqat təd- } \\
\text { birlərinin keçirilməsi }\end{array}$ & 230 & 16.000 & 100 \\
\hline 1.4 & $\begin{array}{l}\text { Bak1 şəhərinin turizm } \\
\text { infrastruk-turunun, o } \\
\text { cümlə dən uyğun }\end{array}$ & 70 & 6.200 & 100 \\
\hline
\end{tabular}




\begin{tabular}{|c|c|c|c|c|}
\hline & $\begin{array}{l}\text { qiy-mətə mehman- } \\
\text { xana və cəlbedi-ci } \\
\text { turizm məkanlarının } \\
\text { inkişaf etdirilməsi }\end{array}$ & & & \\
\hline 2.1 & $\begin{array}{l}\text { Viza rəsmiləşdi- } \\
\text { rilməsi proseslə-rinin } \\
\text { və sərhəd-keçid } \\
\text { prosedur-larının } \\
\text { sadələşdi-rilməsi və } \\
\text { sürət-ləndirilməsi }\end{array}$ & 30 & - & - \\
\hline 2.2 & $\begin{array}{l}\text { Osas tələb bazar-ları } \\
\text { ilə hava əla-qəsinin } \\
\text { təkmilləş-dirilməsi }\end{array}$ & 30 & - & - \\
\hline 3.1 & 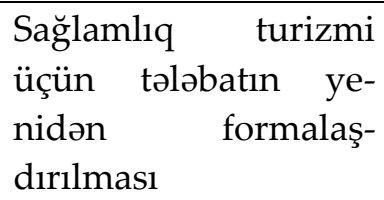 & 50 & 1 & 15 \\
\hline 3.2 & $\begin{array}{l}\text { Q1ş turizminin ink- } \\
\text { işafının dəstəklənməsi }\end{array}$ & 20 & 300 & 15 \\
\hline 3.3 & $\begin{array}{l}\text { Mədəni turizm } \\
\text { marşrutlarının } \\
\text { yaradılması }\end{array}$ & 20 & 3700 & 95 \\
\hline 4.1 & $\begin{array}{l}\text { Turizm sahəsində } \\
\text { təhsil proqram-larına } \\
\text { investisiya qoyuluşu }\end{array}$ & - & 150 & 10 \\
\hline
\end{tabular}

Qeyd etmək lazımdır ki, ölkə iqtisadiyyatına gəlir gətirən sahələrdən biri kimi, turizm Azərbaycanın dünyada tanınmasına imkan yaradır.

Azərbaycan Respublikasında aparılan turizm siyasəti ölkənin davamlı inkişafına yönəldilmişdir.

Vurğulamaq lazımdır ki, Azərbaycanın əlverişli coğrafi vəziyyəti, turistlər üçün cəlbedici olması Cənubi Qafqaz bölgəsində ölkənin turizm mərkəzinə çevrilməsinə geniş imkanlar yaradır. Dünyada qəbul edilmiş 
11 iqlim şəraitindən 9-u Azərbaycanın, yəni onun regionlarının payına düşür ki, bu da ölkənin gözəlliyindən xəbər verir.

Son illərdə ölkə regionlarının sosial - iqtisadi inkişafı ilə bağlı qəbul edilmiş 3 Dövlət Proqramlarının həyata keçirilməsi nəticəsində turizmin inkişafına təkan verilmiş və onun müxtəlif növlərinin inkişafı müşahidə olunmaqdadır. Azərbaycanda inkişaf edən turizm sahələrindən ekoturizm, dini turizm, kənd turizm, su turizm, dağ turizm, tibbi turizm və s. göstərmək olar.

Qeyd etmək lazımdır ki, turizm sahəsində məşğul olanlar əsasən gənclər təşkil edir. Bu sahədə kadr hazırlığ Menecment Universiteti tərəfindən həyata keçirilir. Yüksək ixtisaslı kadr hazırlı̆̆ının təmin olunması keyfiyyət göstəricilərinin əldə olunmasına zəmin yaradır. Müxtəlif ölkələrdə praktika keçən bu gənclər, öz təcrübələrini ölkənin otel və mehmanxanalarında tətbiq edirlər.

\section{Natica:}

Beləliklə, Azərbaycanda aparılan gənclər siyasəti və turizm siyasəti arasında tarazlıq mövcuddurki, bu da gənc kadrlardan səmərəli istifadə olunmasına yönəldilmişdir.

\section{Odəbiyyat}

Milli Məclis, (2014), Azərbaycan Respublikasının 2015-ci il Dövlət Büdcəsinin zərfi. Bakı, 84

Sultanova R.P. (2016), Azəebaycan gənclərinin ölkə iqtisadiyyatında rolu. Beynəlxalq konqress, Türkiya, Muğla Sitki Koçman Universiteti, 463-467

Azərbaycan Respublikasında ixtisaslaşmış turizm sənayesinin inkişafına dair Strateji Yol Xəritəsi, Bakı, 2016, 83 


\section{Kaynakça Bilgisi / Citation Information}

Sultanova, R. (2018). Azərbaycanda Gənclər Siyasəti Və Onun Turizmin İnkişafına Təsiri. OPUS - Uluslararası Toplum Araştırmaları Dergisi, 8(Gençlik Araştırmaları Özel Sayısı), 391-397. 